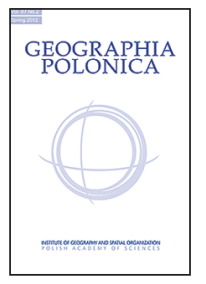

\title{
CONTROL FUNCTIONS WITHIN LARGE CITIES AND FOREIGN DIRECT INVESTMENT IN THE TRANSPORT SECTOR: EMPIRICAL EVIDENCE FROM POLAND*
}

\author{
Zbigniew Taylor • Ariel Ciechański \\ Institute of Geography and Spatial Organization \\ Polish Academy of Sciences \\ Twarda 51/55, 00-818 Warsaw: Poland \\ e-mails: z.taylor@twarda.pan.pl・ariel@twarda.pan.pl
}

\begin{abstract}
On the basis of inventory research carried out by the authors on single transport FDI, a hierarchy of the ten largest Polish cities is created, and then related to the number of inhabitants. The paper focuses on the location of corporate headquarters (HQs) serving various control (decision-making) functions and simultaneously playing an urban-creative role. The analysis confirms in part only the idea that the more advanced the branch of the economy, the more the city in which a corporate $\mathrm{HQ}$ is located is likely to occupy a higher rank in the administrative hierarchy, with a simultaneous large number of affiliates. The findings arise out of in-depth research, albeit on the basis of a relatively small number of incidences of foreign investment in the Polish transport sector. Whether it is the criteria of absolute amount of capital invested, number of employees or number of controlled investments, it is consistently the city of Warsaw and its metropolitan area that tops the rankings. Alongside inter-urban differentiation in transport FDI, analysis also confirms substantial intra-urban variation.
\end{abstract}

\section{Key words}

transport $\cdot \mathrm{FDI} \cdot$ control functions $\cdot$ corporate headquarters $\bullet$ large cities $\cdot$ Poland

\section{Introduction}

The cities of Central and Eastern Europe (CEE) have been the subject of far-reaching systemic transformation for over two decades now. The various facets to this transfor- mation include the subject matter of this article and the work underpinning it, which has sought to answer such cognitive questions as: (1) what is the attractiveness of Poland's largest cities and their metropolitan areas where foreign capital invested in transport is

\footnotetext{
The former version of this paper appeared in Przegląd Geograficzny (as Taylor \& Ciechański 2014).
} 
concerned?; (2) what is the hierarchy of large cities and their metropolitan areas from the point of view of the distribution of the corporate headquarters of foreign transport companies, and therefore of control functions?; (3) what are the types of transport activity engaged in by companies with $\mathrm{HQs}$ located in the largest cities and their metropolitan areas?; and (4) what are the locations of corporate HQs within the large cities and how may we account for these? Underlying the analysis is in turn an assumption that the attraction of FDI from whatever source is generally encouraged as a means of stimulating urban and regional development.

This paper goes on to envisage foreign companies involved in the transport sphere as active subjects performing in Polish space. Transport is a sector in which examples of foreign investment have been fewer in number than elsewhere within the economy (Taylor \& Ciechański 2013). Moreover, there is a much larger share of firms involved in carriage activity, as opposed to the construction of infrastructure, which requires higher capital inputs and only generates profit in the longer term.

There are certain reasons for the more limited nature of investment in transport, including the late interest shown by foreign capital in the case of this sector, the lack of legal regulations facilitating investment at the beginning of the transformation period (especially in the early 1990s), and also - partially - the protective state policy covering the domestic transport market which was as set out in the Accession Treaty signed between Poland and the EU. As a result, there has only been FDI in transport on a more limited scale than has been noted in, for example, commerce, manufacturing, the construction industry or the servicing of real estate.

The subjects of this paper are the ten largest Polish cities - each of more than 300,000 inhabitants, i.e. Warsaw, Kraków, Łódź, Wrocław, Poznań, Gdańsk, Szczecin, Bydgoszcz, Lublin and Katowice, as well as the metropolitan areas thereof. The extent to which foreign capital is located in a given city or region is taken to indicate the level of attractiveness - all the more so since foreign firms are footloose when it comes to their choice of place to operate (Domański et al. 2000; Zakrzewska-Półtorak 2004; Tavares \& Young 2006).

$\mathrm{FDI}$ is understood to comprise investments capable of leading to permanent profitability on the part of a foreign company, thanks to an effective impact on decisions taken as regards the local firm (Stępniak \& Umiński 1993; Luc 2000; Stawicka 2007). In this paper, we have accepted a modified version of the definition from the National Bank of Poland, in line with which those in receipt of FDI are companies under commercial law in which foreign investors own $10 \%$ or more of initial capital, and if this share is smaller, then the total value of foreign capital invested should be no less than 100,000 zloties'. The latter situation is very rare, however, applying in just a few cases. While in line with the NBP definition the two conditions are treated jointly, under the approach taken by the authors, the total value of initial capital is considered only where the share accounted for by the foreign investor does not exceed $10 \%$.

The remainder of the paper is structured as follows. The second section provides brief review of literature, and the third one information on methodology. The next section depicts the attractiveness of urban centres to foreign investors, as measured by reference to the number and size of investments under their control and also the number of employees. Furthermore, the information obtained is sufficient to indicate the detailed location of corporate headquarters in selected cities, and thus portrays intra-urban and inter-urban variation in investments. Some investments are located, not in cities themselves but in their metropolitan areas, which are analysed subsequently. Later on, a spatial score for corporate HQs is provided, before the final section generates conclusions.

\footnotetext{
1 The value of foreign capital invested has been expressed in zloties in line with the then official National Bank of Poland (NBP) exchange rates.
} 


\section{Literature review}

Since there is a burgeoning literature on FDI today, we mention only selected papers, focusing on the newest literature and that relevant to the Polish situation. There is an extensive literature on mechanisms and conditions underpinning cases of FDI (e.g. Hill \& Munday 1992, 1995; Luc 2000; Pavlínek 2004; Tavares \& Young 2006; Stawicka 2007; Pelegrín \& Bolancé 2008; Hilber \& Voicu 2010; Halvorsen 2012; Zhao et al. 2012). Moreover, Qiu (2005) indicates the relations between informal personal networks and institutional involvement as critical in explaining FDI location decisions; while Wei et al. (2010) outline structural changes in the economy underlying the location choices and network configurations of foreign ventures. Soci (2007) attempts to relate empirical results of research to the theoretical structures within the framework of new economic geography. Fallon and Cook (2010) examine the main factors that attract inbound FDI at the UK regional level and its interregional variation. Some papers relate to the location of foreign firms in intra-urban space (Wu 1999, 2000; Yeung et al. 2001; Özdemir 2002; Wu \& Radbone, 2005; Wei et al. 2010). Among more substantial publications one can note recent monographs, for example that from Liebscher et al. (2007) on multidirectional flows of capital and their impact on home and host countries in the CEE region.

However, in dealing with certain foreign papers on FDI in Poland or other countries of the region, a measure of caution is advisable, since there are a number of case studies or works purporting to be of a review nature, but actually based on a paucity of scarce empirical data, supported by false assumptions or inaccurate theoretical interpretations, and on this basis theses doubtful from the factual and methodological points of view but with a great degree of generalization are advanced (Domański 2001b). As a result, expressions such as 'cathedrals in the desert', 'Kuwaitisation' and others appear, which are irrelevant to the described reality (cf. Grabher 1992; Hardy 1998, to mention but a few). More sense and benefit is of use of foreign literature on other countries of CEE where the situation is similar to the Polish one (e.g. Hunya 1998; Pavlínek 1998, 2002, 2004, 2012; Pavlínek \& Smith 1998; Varblane 2001; Vančura 2004, 2006; Pavlínek et al. 2009). A good introduction and interpretation of the problems of FDI in the CEE countries is provided in an economic work edited by Marinova and Marinov (2003).

In the last dozen or so years, a number of substantial publications on FDI in Poland have appeared, mainly of an economic nature. They relate to all FDI (e.g. Karaszewski 2004; Pakulska \& Poniatowska-Jaksch 2004; Cieślik 2005a; Pawlik 2006), or to industrial investment (Luc 2000; Poniatowska-Jaksch 2006), to mention but a few. So far, in geography the most thorough monograph has been the work of Domański (2001a), concerning manufacturing. There is also the much more comprehensive treatment of the transport sector by Taylor and Ciechański (2013).

Selected empirical studies on a smaller scale should also be mentioned. Chidlow et al. (2009) analyse regional determinants of inward FDI distribution in Poland, as does Cieślik, pointing to border effects (Cieślik 2005b), agglomeration effects and the road network (Cieślik 2005c), and firm size (Cieślik 2013) as the most important factors. A common feature of these papers is that all, despite using econometric models, analyse very aggregated data at a regional level and neglect more detailed spatial and subject distribution of the FDI. This is in line with foreign papers (e.g. Tavares \& Young, 2006; Pelegrín \& Bolancé 2008; Fallon \& Cook 2010; Hilber \& Voicu 2010; Halvorsen 2012).

In geography, Domański (2011: 176) interprets determinants and effects of the FDI in Polish regions from the theoretical perspective of dynamic localised capabilities which are 'defined as tangible or intangible resources, embodied in the relationships between enterprises, people and institutions in a given area'. It is in this vein that the 
impact of foreign investment on the development of regions is analysed.

Some authors (e.g. Domański 2001a, 2011; Cieślik 2013) postulate research into determinants of FDI location at the sectoral level, 'instead of grouping together heterogeneous economic activities' (Cieślik 2013: 191) - as has been the most common practice in the majority of research carried out so far. Moreover, the transport sector has been investigated very seldom, not in Poland only, but also worldwide. It is for this reason that the current study can be considered to fill a gap in research to some extent at least.

There is also an extensive literature on control functions (e.g. Śleszyński 2002, 2007, 2008, 2014), which will not be discussed here in line with the limited scale of the paper. As Śleszyński (2002) rightly notes, the distribution of corporate $\mathrm{HQs}$ does not indicate the real spread or power of manufacturing, rather indicating decision-making centres, or the discharge of control functions. The location of corporate $\mathrm{HQs}$ is connected with several (economic, social and political) roles, albeit with the first of the three looking the most important. The placing of a headquarters is also connected to the type of activity: the more advanced the branch of the economy, the more likely that the location of $\mathrm{HQs}$ will be associated with localities higher up in the administrative hierarchy, with simultaneously a large number of affiliates.

\section{Methodology \\ Data collection}

In the face of a paucity of official statistics, the majority of data on FDI came from inventory research carried out by the authors on single transport firms included in Hoppenstedt Bonnier Information Polska (HBI) and on TeleAdreson.pl, as supplemented by some missing data from the Polish Information and Foreign Investment Agency (PAliIZ) and the commercial register REGON (GUS - the Central Statistical Office in Poland). A list of the firms created was then interviewed with relative success (50.6\% responsed), the particular focus being on total capital invested and number of employees in particular branches of foreign transport companies. All suspicious data were checked against information provided by the National Court Registry (Krajowy Rejestr Sadowy), and information made available by InfoVeriti firm (www.infoveriti.pl) as well as from annual reports and official webpages of transport companies. Archival articles in the business press also proved useful. Following the removal of some firms (e.g. those taken over by Polish investors), we obtained a reliable list of instances of FDI in the Polish transport sector.

The source of the basic information for the paper is thus the authors' wider research on this theme (Taylor \& Ciechański 2013), which provides data on the number of companies (in total 330 independent and 47 affiliates, branches and subsidiaries) as of the end of 2008, number of employees in enterprises in 2008, and cumulated value for FDI in contemporarily-existing companies up the end of 2008. Particular reference is given to the spatial aspect of FDI, including location factors, above all as regards greenfield investments.

\section{Data analysis}

Traditional indices of spatial variation such as coefficients of intra-urban and inter-urban variation for the largest Polish cities have been applied. Additionally, Gini coefficients, being an alternative measure of lack of similarity, have been used, along with Lorenz concentration curves showing inequalities of distribution where controlled foreign transport companies are concerned. The latter present the value of capital invested and numbers of employees, and as regards the space of the selected cities analysed. Since the cities studied vary considerably in size, location quotients have been applied to allow for comparisons between number of supervised investments, amounts of capital located and numbers of employees, all of these being related to the number of inhabitants in given cities. 


\section{The attractiveness of large cities to foreign investors in the transport sector}

In line with the indices of attractiveness, transport is among the averagely-attractive branches of the Polish economy (Weresa 2008), while cities, especially large ones, present agglomeration advantages (Chidlow et al. 2009; Halvorsen 2012). In essence, agglomeration economies are considered a key issue in FDI. Up to the year 2008, the ten largest cities attracted foreign investments in transport of total value 4.2 billion zloties, which is to say some $65.6 \%$ of all such investment in Poland. A little smaller, but also substantial, is the share of all FDI in 2008 accounted for by the above-mentioned cities as regards the number of independent companies $(45.5 \%$, or 150$)$, as well as employment $(43.6 \%$, or 21,891 people) (Tab. 1$)$. The location of corporate headquarters is impor- tant, since there is an influence on decisionmaking relevant to significant matters of company management (Yeung et al. 2001; Tonts \& Taylor 2010, 2013). Location also determines the volume of income from local taxes paid by firms.

The centres analysed attract controlled investments to a disproportionate extent when related to population potential - as is confirmed by the high values for location quotients $L Q$ related to the total number of inhabitants of the cities: 2.78 (number of investments), 3.99 (value of investments), and 2.65 (number of employees). The ten cities focus albeit at various different intensities - investments in all types of activity, be that in rail transport, road transport of passengers, road transport of freight, maritime and inland shipping, air transport and airport services, cargo throughput, logistics, forwarding and storage, and mixed and remaining activities. As with manufacturing (Domański et al. 2000) and

Table 1. Foreign investment in the transport sector in the largest Polish cities

\begin{tabular}{|c|c|c|c|c|c|c|c|}
\hline$\vec{\Xi}$ & 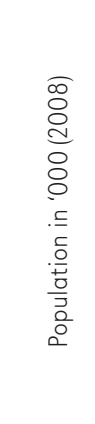 & 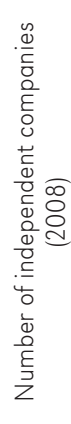 & 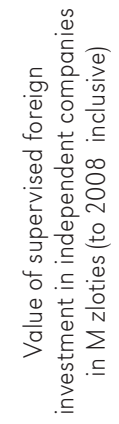 & 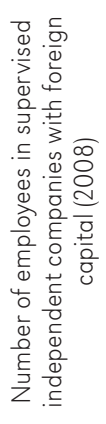 & 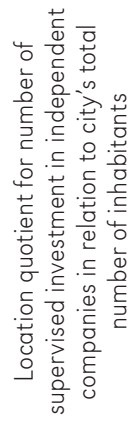 & 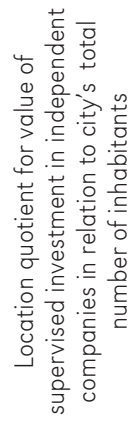 & 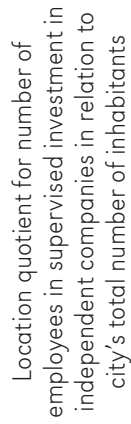 \\
\hline Warsaw & $1,708.5$ & 85 & $2,873.97$ & 17,754 & 5.75 & 9.98 & 7.90 \\
\hline Gdańsk & 460.5 & 8 & $1,072.71$ & 339 & 2.02 & 13.97 & 0.57 \\
\hline Poznań & 553.6 & 14 & 87.45 & 920 & 2.90 & 0.93 & 1.26 \\
\hline Bydgoszcz & 363.0 & 2 & 75.76 & 94 & 0.64 & 1.25 & 0.20 \\
\hline Wrocław & 631.2 & 3 & 50.11 & 608 & 0.55 & 0.47 & 0.73 \\
\hline Szczecin & 409.6 & 21 & 41.86 & 1,521 & 6.25 & 0.61 & 2.84 \\
\hline Łódź & 725.1 & 8 & 10.14 & 245 & 1.39 & 0.08 & 0.25 \\
\hline Kraków & 759.1 & 6 & 6.21 & 365 & 0.92 & 0.05 & 0.37 \\
\hline Lublin & 348.6 & 1 & 0.58 & 11 & 0.33 & 0.01 & 0.02 \\
\hline Katowice & 309.3 & 2 & 0.12 & 34 & 0.37 & 0.00 & 0.08 \\
\hline 10 cities (total) & $6,268.5$ & 150 & $4,218.89$ & 21,891 & 2.78 & 3.99 & 2.65 \\
\hline Poland total & $x$ & 330 & $6,425.90$ & 50,156 & 1.00 & 1.00 & 1.00 \\
\hline
\end{tabular}

Population from Rocznik Statystyczny RP 2008, GUS, Warszawa 
all FDI (Szymański 2002; Domański 2011), a majority of the large-city transport investments are oriented towards the domestic Polish market, rather than export.

There is great differentiation to foreign investments in transport amongst the selected cities. Definitely making a mark is Warsaw - in which $44.7 \%$ of all the foreign capital in the Polish transport sector has been invested (2.87 billion zloties) and 35.4\% of the total number of jobs created. Next comes the city of Gdańsk (1.07 bn zloties, but only 1.5\% of the jobs). Controlled investments in the cities of Poznań, Bydgoszcz, Wrocław and Szczecin are of several dozen million zloties, while levels in the four remaining cities are much lower.

Of greater interest is the comparison between amounts of capital located and the number of inhabitants in given cities. From this point of view the greatest concentration of foreign investment is in Gdańsk $(L Q=13.97)$, in which extremely capital-intensive infrastructural investments can be seen to have taken place. Warsaw takes second position ( $L Q=9.98)$ in this regard, while among the eight remaining cities it is only in the case of Bydgoszcz that a location quotient above one is to be noted. In the remaining seven cities, capital inputs in transport are much more limited than their population potential might imply.

A somewhat different picture emerges when numbers of employees are set against numbers of inhabitants of the given cities. Warsaw is again seen to lead all other centres (with $L Q=7.90$ ), while second place is this time taken by the city of Szczecin $(L Q=2.84)$, with Poznań $(L Q=1.26)$ in third. The remaining seven cities have location quotients below one, indicating more limited concentration of employment in these centres.

A majority of the foreign investment in large cities (e.g. in Warsaw, Bydgoszcz and Wrocław) has taken the form of acquisitions of existing transport enterprises. Among the larger brownfield investments are those associated with the corporate HQs in Warsaw - despite reckoning new investments (e.g. Mil- itzer \& Münch, Maersk, EuRoPol GAZ). When the value of greenfield investment is taken into account, such majorities are observed in the cities of Gdańsk (the Deepwater Container Terminal, uncompleted EuroPort), Szczecin (e.g. Odra Lloyd), or Kraków, but their total capital inputs have been smaller than takeovers. This regularity is confirmed in the situation for Poland as a whole.

\section{Intra-urban and inter-urban differentiation in foreign transport investments}

Research into the distribution of corporate headquarters in intra-urban space has a long tradition. Studies have i.a. been carried out by Kato and Yamazaki (1981), Wheeler (1988), Chiba (1992), Yeung et al. (2001), Wu and Radbone (2005), Tonts and Taylor (2010), Wei et al. (2010), Huang and Wei (2014), and in Poland - by Śleszyński (2002).

What is the differentiation to foreign investment in transport across the largest Polish cities? There is no doubt that Warsaw is the most important, but also extremely dominant, centre, concentrating control functions over more than half of the foreign transport companies operating in the ten largest cities analysed. 85 independent companies out of a total number of 150 such companies with various types of activity have their $\mathrm{HQs}$ in the capital city. A majority of companies are located in the area of the airport, with the southern rim of left-bank Warsaw in second place, and then the CBD (Fig. 1). With greater distance from the centre, the number of firms decrease, but the radius within which they occur is the largest to be observed in any of the cities analysed (up to $14 \mathrm{~km}$ ).

In the city of Szczecin there are 21 corporate HQs of companies, a majority of which are focused around the port and in the adjacent urban area. In the city centre there are just two firms. In Poznań, there are 14 companies headquartered, involved in two types of activity: the road transport of freight and cargo throughput, logistics, forwarding and storage. The course of the A2 motorway 

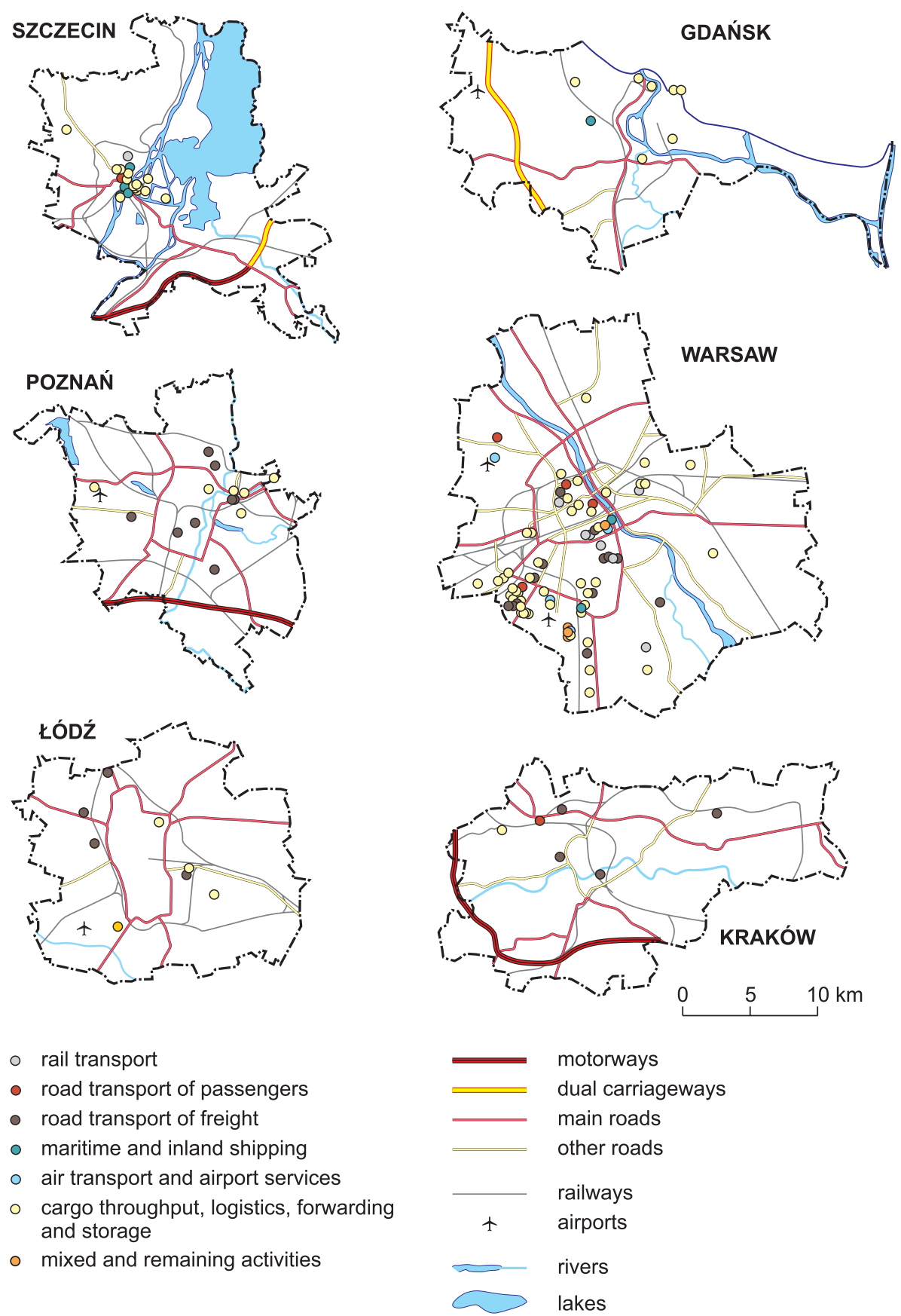

Figure 1. Locations of the corporate headquarters of foreign transport companies in selected cities of Poland 
is not seen to influence the location of companies.

Two cities - Gdańsk and Łódź - each play host to the corporate HQs of eight companies. In the former there are large companies engaged in cargo throughput, logistics, forwarding and storage, plus one rather small firm involved in maritime passenger shipping. By and large, companies are spread across urban space. Like Gdańsk, the city of Łódź has eight foreign companies headquartered in it. However, unlike Gdańsk, these are rather smaller firms: all are spread through the inner and outer zones of the city, but beyond the city centre itself.

In the city of Kraków there are just six corporate HQs of foreign transport companies. Four firms are located in the northern suburbs, two close to the city centre. There is no influence of the course of the A4 motorway on the location of companies. The remaining large cities - Wrocław, Bydgoszcz, Katowice and Lublin - have each attracted between three and one instances of foreign transport investment.

Lorenz concentration curves show inequalities of distribution where controlled foreign transport companies are concerned, as measured in terms of the value of capital invested and numbers of employees, and as regards the space of the six cities analysed (Fig. 2). All curves deviate from the diagonal. Relatively smaller disproportions between the volume of capital invested and number of employees are observed in the case of Łódź (inputs more proportional to employment), while the most marked ones characterise Poznań, in which relatively limited inputs of foreign capital are accompanied by substantial employment. The situation of the remaining cities - Gdańsk, Kraków, Szczecin and Warsaw is intermediate.

To describe briefly the intra-urban and then inter-urban differentiation in foreign investment in transport, coefficients of intraurban $\left(V_{w}\right)$ and inter-urban $\left(V_{m}\right)$ variation and Gini coefficients have been used. In our case the coefficient of variation is related to standard deviation from the arithmetic mean and is expressed as a percentage (Tab. 2). $V_{w}$ coefficients of variation and Gini coefficients, taking into account the number of companies, number of employees and capital invested, are computed between concentric circles of central cities.

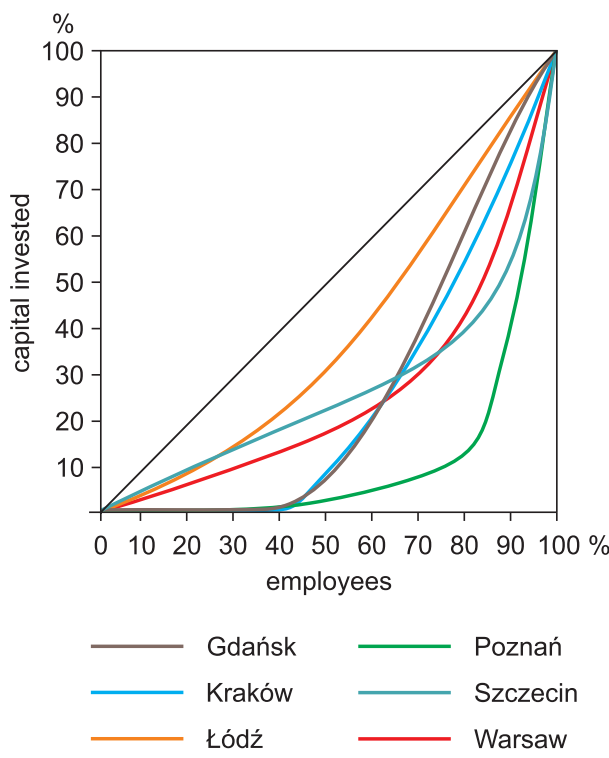

Figure 2. Lorenz concentration curves for the distribution of foreign transport companies in selected cities

Of course, the situation of single cities is different. A majority of the cities analysed (other than Lublin and Bydgoszcz with their very few cases of FDI) show the greatest variation $V_{w}$ in line with capital invested, a reflection of the fact that practically each city has gained different investments of various sizes. The most marked variation is that characterising Kraków $\left(V_{w}=214.51 \%\right)$ and Poznań $\left(V_{w}=205.36 \%\right)$, while values for Warsaw and Wrocław are somewhat lower.

Szczecin presents the greatest internal variation as regards the numbers of employees in given firms $\left(V_{w}=183.67 \%\right)$. Relatively marked variation is also visible in Wrocław, Warsaw, Kraków, Poznań and Gdańsk. When numbers of companies are taken into account, the greatest variation is found to be that for Gdańsk and Szczecin, ahead of Poznań and Warsaw. Reference to the Gini coefficients 
basically confirms the trends observed before (Tab. 2).

Coefficients of inter-urban variation $V_{m}$ and Gini coefficients allow for a characterisation of inter-urban variation in foreign investment in transport. The group of cities analysed is mostly differentiated when number of employees is taken into account $\left(V_{m}=250.73\right)$, less so in the case of capital invested $\left(V_{m}=218.50\right)$, and even less as regards number of companies $\left(V_{m}=169.15\right)$. But the values of Gini coefficients show great similarity of concentration of foreign transport companies among the various cities (Tab. 2). The largest concentration of transport companies is seen to be present when capital invested is taken into account $\left(I_{G}=0.8949\right)$, less so with number of employees $\left(I_{G}=0.8900\right)$, and least of all (but still tangible) in regard to the number of companies $\left(I_{G}=0.7526\right)$. on this subject (cf. Czyż 2009; Korcelli-Olejniczak 2012), which will be not described here for obvious reasons. In this paper, the metropolitan area (beyond a city centre) is defined, with some simplification, as a suburban zone extending to $30 \mathrm{~km}$ road distance from the outer limits of the central city, and the cities creating the core of the Upper Silesian District (Tab. 3, note ${ }^{b}$ ). In the case of the city of Warsaw, the boundaries of the metropolitan area are extended up to $60 \mathrm{~km}$ from the borderline of the capital city. Metropolitan areas outlined in this way coincide with zones of the most intensive commuting to the largest cities and the cities of Upper Silesian conurbation.

Altogether, metropolitan areas of the largest cities concentrate controlled investments of over 5.9 billion zloties, that is $92.7 \%$ of the total value of foreign investment in transport

Table 2. Coefficients of intra-urban $V_{w}$ and inter-urban $V_{m}$ variation plus Gini coefficients $I_{G}$ for the largest Polish cities

\begin{tabular}{|l|c|c|c|c|c|c|}
\hline \multirow{2}{*}{ City } & \multicolumn{3}{|c|}{ Coefficients of variation } & \multicolumn{3}{c|}{ Gini coefficients } \\
\cline { 2 - 7 } & $\begin{array}{c}\text { number of } \\
\text { companies }\end{array}$ & $\begin{array}{c}\text { number of } \\
\text { employees }\end{array}$ & $\begin{array}{c}\text { capital } \\
\text { invested }\end{array}$ & $\begin{array}{c}\text { number of } \\
\text { companies }\end{array}$ & $\begin{array}{c}\text { number of } \\
\text { employees }\end{array}$ & $\begin{array}{c}\text { capital } \\
\text { invested }\end{array}$ \\
\hline Gdańsk & 83.85 & 100.67 & 145.12 & 0.3750 & 0.6077 & 0.8178 \\
Katowice & 0.00 & 16.64 & 25.50 & 1.0000 & 0.1176 & 0.1803 \\
Kraków & 37.27 & 125.08 & 214.51 & 0.6667 & 0.7342 & 0.9695 \\
Łódź & 55.90 & 85.56 & 115.21 & 0.5000 & 0.5204 & 0.6910 \\
Poznań & 75.05 & 114.81 & 205.36 & 0.5143 & 0.8896 & 0.9314 \\
Szczecin & 81.44 & 183.67 & 133.03 & 0.5238 & 0.9057 & 0.7566 \\
Warsaw & 67.14 & 125.12 & 196.37 & 0.5235 & 0.6741 & 0.8308 \\
Wrocław & 0.00 & 158.32 & 172.43 & 1.0000 & 0.9293 & 0.9960 \\
\hline Total ${ }^{b}$ & 169.15 & 250.73 & 218.50 & 0.7526 & 0.8900 & 0.8949 \\
\hline
\end{tabular}

a $V_{w}$ and $I_{G}$ computed for variation betweeen concentric circles of analysed cities, respectively;

${ }^{b}$ For all 10 cities, including Bydgoszcz and Lublin: $V_{\mathrm{m}}$ and $I_{G}$ computed for variation among analysed cities, respectively.

\section{Foreign investments in the transport sector located in metropolitan areas}

Consideration of foreign investment in large cities should not ignore the wider metropolitan areas. There is an extensive literature in Poland as a whole. The average share accounted for by central cities is $70.8 \%$, with the remaining being accounted for by outer zones of urban regions(Tab. 3). This is to say that the concentration of foreign transport-related investments in metropolitan areas is much greater than that involving, for example, 
Table 3. Foreign investment in the transport sector in Poland's metropolitan areas

\begin{tabular}{|c|c|c|c|c|c|}
\hline \multirow[b]{2}{*}{$\begin{array}{l}\text { Metropolitan } \\
\text { area of }\end{array}$} & \multirow{2}{*}{$\begin{array}{c}\text { Value } \\
\text { of supervised } \\
\text { foreign } \\
\text { investment } \\
\text { in M zloties } \\
\text { (to } 2008 \text { inclusive) }\end{array}$} & \multicolumn{2}{|c|}{$\begin{array}{l}\text { \% shares of total value } \\
\text { of supervised investment }\end{array}$} & \multirow{2}{*}{$\begin{array}{c}\text { Value } \\
\text { of supervised } \\
\text { greenfield } \\
\text { investment } \\
\text { in M zloties } \\
\text { (to 2008 inclusive) }\end{array}$} & \multirow{2}{*}{$\begin{array}{c}\text { Number of } \\
\text { employees } \\
\text { in supervised } \\
\text { foreign companies } \\
\text { (2008) }\end{array}$} \\
\hline & & $\begin{array}{l}\text { central } \\
\text { city }\end{array}$ & $\begin{array}{c}\text { suburban zone } \\
\text { up to } 30 \mathrm{~km} \text { from } \\
\text { limits of central } \\
\text { city }^{\text {a }}\end{array}$ & & \\
\hline Warsaw & $3,024.0$ & 94.1 & 5.9 & 868.4 & 22,787 \\
\hline Gdańsk & $1,320.1$ & 81.2 & 18.8 & 686.9 & 1,492 \\
\hline Upper Silesia ${ }^{b}$ & $1,163.4$ & $10.0^{c}$ & 90,0 & 85.3 & 6,575 \\
\hline Poznań & 246.5 & 35.6 & 64.4 & 85.5 & 8,973 \\
\hline Bydgoszcz & 75.8 & 100.0 & 0.0 & - & 94 \\
\hline Wrocław & 60.9 & 82.3 & 17.7 & 6.2 & 1,315 \\
\hline Szczecin & 44.8 & 82.3 & 17.7 & 27.6 & 1,581 \\
\hline Łódź & 16.0 & 63.3 & 36.7 & 10.2 & 375 \\
\hline Kraków & 6.2 & 100.0 & 0.0 & 5.1 & 365 \\
\hline Lublin & 0.6 & 100.0 & 0.0 & 0.6 & 11 \\
\hline $\begin{array}{l}10 \text { metropolitan } \\
\text { areas (total) }\end{array}$ & $5,958.3$ & 70.8 & 29.2 & $1,775.6$ & 43,568 \\
\hline Poland total & $6,425.9$ & - & - & $1,958.6$ & 50,156 \\
\hline
\end{tabular}

a In the case of the Warsaw metropolitan area localities within a radius of up to $60 \mathrm{~km}$ road distance from the administrative limits of the city, and $30 \mathrm{~km}$ from the outer boundaries of the cities of the Upper Silesian conurbation 'core';

b 'Core' of the Upper Silesian district (cities of Gliwice, Bytom, Zabrze, Ruda Śląska, Świętochłowice, Chorzów, Siemianowice Śląskie, Katowice, Mysłowice, Sosnowiec, Będzin and Dąrowa Górnicza);

c Including city of Katowice $-0.01 \%$.

manufacturing (Domański et al. 2000), in that industrial plants are much more dispersed. At the same time, we should note that new investment in metropolitan areas represents only $29.8 \%$ of all investment (a little less than in the country as a whole). The total share of employees accounted for by the analysed urban areas is $86.7 \%$, i.e. very close to the relevant share of capital inputs, and only just over half as great as in the central cities. This in general denotes that investment in metropolitan areas (excluding central places) is less capital-intensive, but creates far more employment opportunities. A similar regularity is observed with production investments (Domański et al. 2000).

A good index of the attractiveness of metropolitan areas is provided by new investment in transport. In this respect, the metropolitan areas of Warsaw (868.4 million zloties) and Gdańsk (686.9 million) are seen to be particularly favoured, having received
$48.9 \%$ and $38.7 \%$ respectively of the total amount, as well as 44.3 and $35.1 \%$ of the overall investment in greenfield sites in Poland. The domination exerted by the Warsaw metropolitan area can be associated with the city being the seat of the central administration and offices, and with ready communication with the rest of the world, the existence of many special services, and the greater ease with which managerial staff may be attracted. In the Gdańsk area, an additional factor is the favoured coastal location in relation to a wide hinterland (embracing, not only Poland, but also neighbouring countries), the skills displayed by the regional authorities when it has come to attracting foreign capital, and successful competition between the two large seaports. In Poznan and the Upper Silesian areas, the value of new transport investment is only a fraction as high, while the Szczecin area has drawn even more. 


\section{The spatial scope of the corporate HQs of transport companies as set against the hierarchy of large cities}

The rank of a centre in an urban hierarchy can be expressed through its ability to attract, not only foreign capital, but also corporate headquarters, particularly of companies whose activity is carried out beyond the centre itself. The location of HQs is identified with control functions fulfilled by a city (Pred 1974; Burns 1977; Hayter 1997; Domański et al. 2000; Guzik \& Gwosdz 2000; Yeung et al. 2001; Tonts \& Taylor 2010, 2013). In the distribution of foreign corporate headquarters, control functions are ascribed to that centre in Poland in which the seat of company subordinated directly to a foreign $\mathrm{HQ}_{\mathrm{s}}$ is located, or a seat of parent company being the main foreign shareholder.

The importance of the ten analysed cities in terms of the control functions discharged is much greater than the value of the capital invested. Corporate HQs located in the analysed cities control $65.5 \%$ of capital and $43.6 \%$ of the employees in the foreign transport sector in Poland (Tab. 1). By contrast, the role played by the remaining parts of metropolitan areas as places in which $\mathrm{HQ}$ s are located is relatively small, with one exception. The Upper Silesian metropolitan area has corporate HQs spread among six counties and nine cities of the conurbation, while the role of the city of Katowice itself is very much limited.

For geographers, the spatial scope of control functions is a matter of particular interest. In these terms, the largest city, of unique type, is Warsaw - from which companies all over Poland are supervised; the exception being the environs of the city of Łódź, as well as Wielkopolska region, especially that part around the city of Poznań (Fig. 3).

In Warsaw, corporate HQs are maintained by CTL Logistics Group - with affiliates in Poland, Germany, the Czech Republic, Ukraine and Romania, engaging in the carriage of freight, including chemicals and hazardous substances, across almost the whole of Europe ${ }^{2}$. In Poland, it is mainly rail transport and throughput, but also forwarding, international road traffic and complex accompanying services that are provided by a dozen or so companies. The largest of these are located in Sosnowiec, Katowice, Kędzierzyn-Koźle, Warsaw, Bydgoszcz, Gdańsk and Gdynia. The capital city also hosts the headquarters of Rail Polska, the purchaser of two firms, which have become their regional branches after transformation. Other companies in rail transport also have their HQs in Warsaw (e.g. Polzug Intermodal Polska, Arriva Polska and Freightliner).

In Warsaw we also find the corporate headquarters of two other brownfield companies, this time in passenger road transport: Veolia Transport Polska, which consolidated 16 firms altogether, and the much smaller Orbis Transport. In air transport and airport services the dominance of Warsaw is particularly well visible. Corporate $\mathrm{HQs}$ have been established here by such companies as LOT Polish Airlines, EuroLOT, Loyd's Aviation Group Polska, Air Logistics and Direct Fly. In freight road transport larger affiliates (outside Warsaw) are located in Szczecin and Puławy only. Where other types of activity are concerned, the HQs only control companies located in Warsaw itself.

Quite different, in the sense of being much smaller is spatial scope, are the companies with headquarters located in the remaining nine cities analysed. Their corporate HQs only control companies situated in the home centres. It is worth taking a closer look at three of the cities which support a relatively large number of companies (Fig. 3).

In Poznań city there are headquarters of 14 companies in cargo throughput, logistics, forwarding and storage, as well as the road transport of freight. An absolute majority

\footnotetext{
${ }^{2}$ The takeover of CTL Logistics in 2008 was the largest acquisition of a company from the primary owner on the Polish market, and the second largest in terms of value ever to take place in Poland (value 1.5 bn zloties).
} 

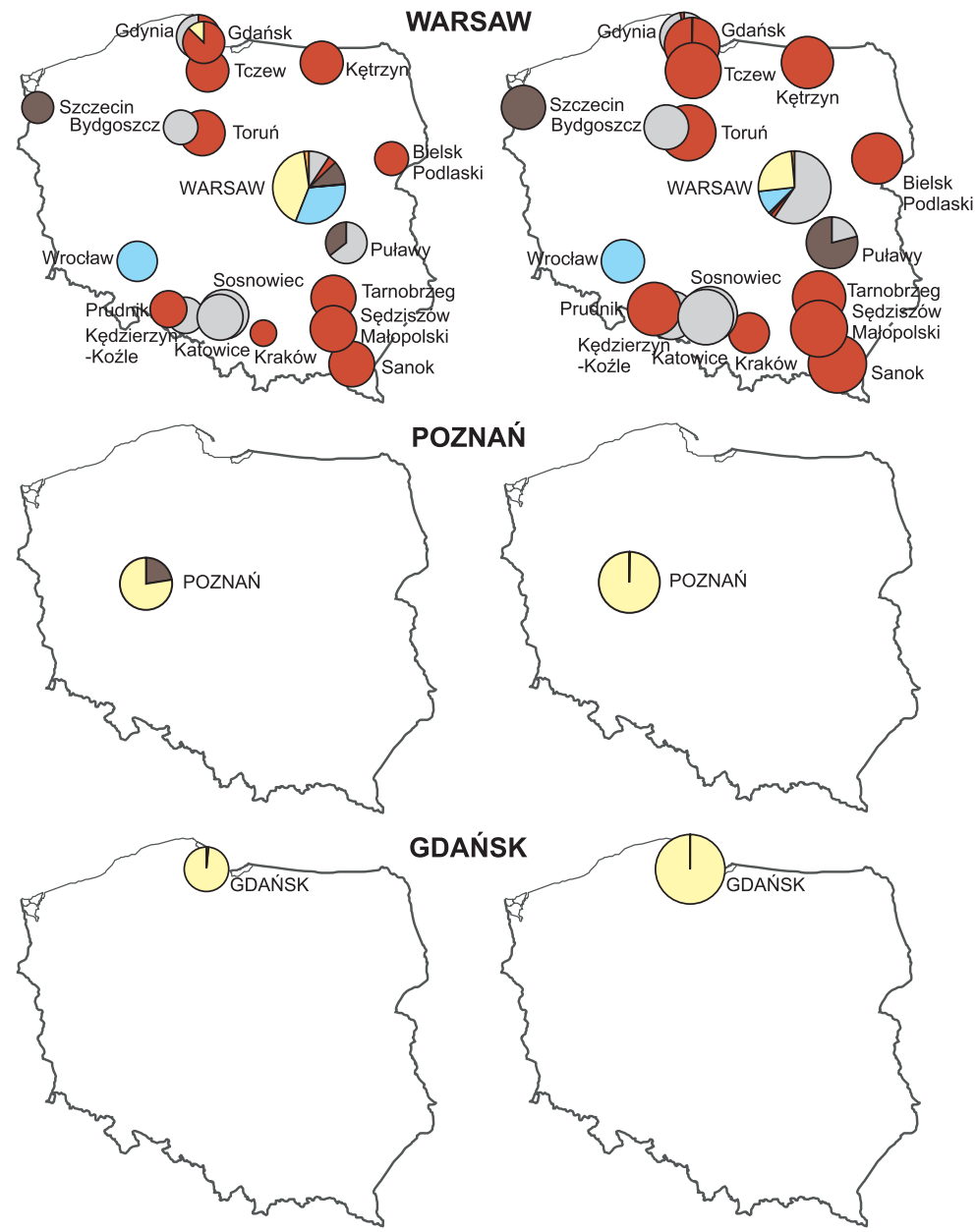

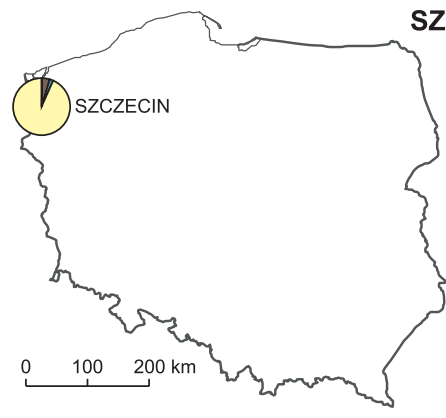

NUMBER OF EMPLOYEES

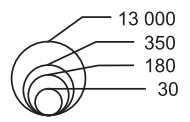

SZCZECIN

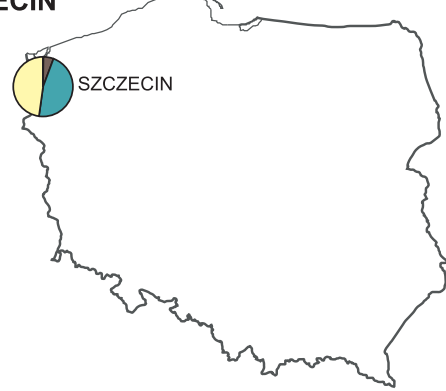

CAPITAL INVESTED (M ZLOTIES)

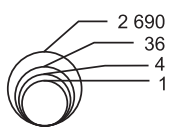

TYPE OF ACTIVITY

$\nabla$ rail transport

$\nabla$ road transport of passengers

$\nabla$ road transport of freight

$\nabla$ maritime and inland shipping

$\nabla$ air transport and airport services

$\nabla$ cargo throughput, logistics, forwarding and storage

$\nabla$ mixed and remaining activities

Figure 3. The distribution of independent and dependent foreign transport companies supervised by corporate headquarters located in the cities of Warsaw, Poznań, Gdańsk and Szczecin (logarithmic scale) 
of the firms are of medium and small size, the one exception being Schrader Internationale Logistic, a greenfield company of European scope.

In Gdańsk likewise, there is an absolute predominance of companies in cargo throughput, logistics, forwarding and storage, at least where employment and capital invested are taken into account. A similar situation as regards employment also characterises Szczecin. However, when capital inputs are considered, the companies in cargo throughput, logistics, forwarding and storage are seen to be augmented at an equal level by companies involved in maritime and inland shipping. Nevertheless, compared with in Gdańsk, the share of new investments in Szczecin is much smaller.

The situation to be observed in Poznań, Gdańsk, Szczecin and other cities analysed (beyond Warsaw) is basically different from that in Polish manufacturing. In the latter case, the role played by out-of-Warsaw centres is much more limited than that applying to the capital, though corporate HQs do control subsidiaries located outside the relevant city. This results in part from the different organisation of manufacturing (frequently consisting of many units) and transport firms. In transport it is independent companies that dominate, with dependent firms accounting for only $12.5 \%$.

\section{Conclusions}

The effects of FDI on the urban system have been profound, but are uneven from the geographical point of view. However, a comparison of levels of investment with population sizes computed by Spearman rank correlation coefficients reveals no statistical significance at any of the accepted levels.

The focusing of transport investments in metropolitan areas reflects availability of information, the presence of state-level administrative institutions, the presence of business services (Pelegrín \& Bolancé 2008), the role of these areas as markets and places of good accessibility, the high skills levels of managers and staff, and visible preferences demonstrated by investors. Is it really true that the more advanced the branch of the economy, the more the location of corporate headquarters is likely to be linked with a higher rank in the administrative hierarchy, with a simultaneous large number of affiliates, subsidiaries and branch companies as Śleszyński (2002) pointed out? The analysis that has been carried out confirms this idea in part only, though it should be remembered that the conclusions are drawn on the basis of a relatively small number of incidences of FDI in the Polish transport sector.

The analysis confirms the dominant position of the city of Warsaw. While we are now 25 years on from the termination of the centrally planned economy whose key feature was the location of many centres of management in the capital, there remain many corporate HQs in which foreign capital has been located. Today presence here represents a conscious choice, since companies have much freedom in their selection of seats and headquarters. Some corporate $\mathrm{HQ}$ s control companies located in the capital city, but many affiliates are dispersed around Poland. The prevalence of one centre focusing disproportionately many control functions is not a Polish specificity. A similar situation, sometimes called a 'strong core effect' can be found in other European countries, for example in the UK (Hill \& Munday 1992, 1995) and Spain (Pelegrín \& Bolancé 2008), but also in the transition economies of the CEE region (Hilber \& Voícu 2010). The latter phenomenon is explained in terms of well-developed infrastructure, the existence of many state enterprises in the process of being privatised, a skilled labour force, and a higher level of knowledge of the language of the potential foreign investor (Varblane 2001; Pavlínek 2004), and large size of local market (Chidlow et al. 2009).

The gap between the premier league capital city and first-division cities is marked. The role played by Poland's second-tier cities is much more limited, but in their case too agglomeration advantages and synergy 
effects can be seen. 65 corporate headquarters located there control affiliates seated in their home cities only. Nevertheless, the value of capital inputs allows for three groups of centres to be distinguished. Definitely ahead among them is the city of Gdańsk which, despite only eight independent transport companies, has gained investment of higher overall value than anywhere else except Warsaw. This is a favourable circumstance since large greenfield infrastructural investments form part of the phenomenon. The city has been able to discount an advantageous coastal location, and to upgrade the Northern Harbour, hitherto left incomplete for the whole period from the 1970s. Today's Deepwater Container Terminal Gdańsk is the largest maritime terminal by the Baltic Sea, and enjoys brilliant prospects for development.

The second group of non-Warsaw centres comprises Poznań, Bydgoszcz, Wrocław and Szczecin, each of which have received supervised transport investment of several tens of millions of zloties. Finally, a third group includes the remaining four analysed cities (Łódź, Kraków, Lublin and Katowice), which only gained transport-related investment at much lower levels.

\section{References}

BURNS L.S., 1977. The location of headquarters of industrial companies: A comment. Urban Studies, vol. 14, no. 2, pp. 211-214.

CHIBA A., 1992. The locational changes of branch offices in Kagoshima City and their territories. Annals of the Japan Association of Economic Geographers, vol. 38, no. 3, pp. 16-32.

Chidlow A., Salciuviene L., Young S., 2009. Regional determinants of inward FDI distribution in Poland. International Business Review, vol. 18, no. 3, pp. 119-133.

CIEślIK A., 2005a. Geografia inwestycji zagranicznych. Przyczyny i skutki lokalizacji spółek z udziałem kapitału zagranicznego w Polsce.
A comparison of levels of investment in the latter two groups with medium-size cities reveals no differences. An example is Gdynia, with its several large companies and corporate HQs, to say nothing of affiliates. The role and significance of this city as regard investment attracted are much more greater than in the cases of certain larger centres like Lublin, Katowice, and even Kraków or Łódź.

Thus, the hierarchy of the largest cities in regard to the level of foreign investment in transport is not identical to the hierarchy of cities in terms of numbers of inhabitants. Nevertheless, the results provide compelling evidence of core-periphery structure.

The foreign investors locating their activities and capital in Poland contribute to growth of cities and regions as broadly construed, but also to the modernization of transport itself (including impact on the competition of carriage, accelerated modernization work and introduction of new technologies, new management systems, and new types of activity).

Editors' note:

Unless otherwise stated, the sources of tables and figures are the authors', on the basis of their own research.

Warszawa: Wydawnictwa Uniwersytetu Warszawskiego.

CIEŚLIK A., 2005b. Location of foreign firms and national border effects: The case of Poland. Tijdschrift voor Economische en Sociale Geografie, vol. 96, no.3, pp. 287-297.

CIEŚLIK A., 2005c. Regional characteristics and the location of foreign firms within Poland. Applied Economics, vol. 37, no. 8, pp.863-874.

CIEŚLIK A., 2013. Determinants of the location of foreign firms in Polish regions: Does firm size matter? Tijdschrift voor Economische en Sociale Geografie, vol. 104, no. 2, pp.175-193.

CZYŻ T., 2009. Koncepcje aglomeracji miejskiej i obszaru metropolitalnego w Polsce. Przeglad Geograficzny, vol. 81, no. 4, pp. 445-459. 
DomańSKI B., 2001a. Kapitał zagraniczny w przemyśle Polski. Prawidłowości rozmieszczenia, uwarunkowania i skutki. Kraków: Instytut Geografii i Gospodarki Przestrzennej UJ.

Domański B., 2001b. Deformacje metodologiczne $i$ ideologiczne $w$ badaniach przekształceń przestrzeni gospodarczej Europy Środkowej i Wschodniej [in:] H. Rogacki (ed.), Koncepcje teoretyczne i metody badań geografii społeczno-ekonomicznej i gospodarki przestrzennej, Poznań: Bogucki Wydawnictwo Naukowe, pp. 27-35.

DOMAŃSKI B., 2011. Foreign capital and the development of Polish regions. Czasopismo Geograficzne, vol. 82, no. 1-2, pp. 173-187.

Domański B., GuzIK R., Gwosdz K., 2000. Konkurencyjność i ranga wielkich miast Polski w świetle inwestycji zagranicznych firm produkcyjnych. Biuletyn KPZK PAN, 192, pp. 99-124.

FAllon G., Cook M., 2010. Exploring the regional distribution of inbound foreign direct investment in the UK in theory and practice: Evidence from a five-region study. Regional Studies, vol. 44, no. 3, pp. 337-353.

GrabHeR G., 1992. Eastern conquista: The truncated industrialisation of East European regions by large West European corporations [in:] H. Ernste, V. Meier (eds.), Regional development and contemporary industrial response: Extending flexible specialisation. London: Belhaven Press, pp. 219-232.

GuzIK R., Gwosdz K., 2000. The spatial concentration of control functions in Polish industry [in:] T. Marszał (ed.), Local economy and urban development in Poland. Łódź: Department of the Built Environment and Spatial Policy. University of Łódź, pp. 52-61.

Halvorsen T., 2012. Size, location and agglomeration of inward foreign direct investment (FDI) in the United States. Regional Studies, vol.46, no.5, pp. 669-682.

HaRDY J., 1998. Cathedrals in the desert? Transnationals, corporate strategy and locality in Wroclaw. Regional Studies, vol. 32, no. 7, pp. 639-652.

HAYTER R., 1997. The dynamics of industrial location. Chichester: John Wiley \& Sons.

Hilber C.A.L., Volcu I., 2010. Agglomeration economies and the location of foreign direct investment: Empirical evidence from Romania. Regional Studies, vol. 44, no. 3, pp. 355-371.
HILl S., Munday M., 1992. The UK regional distribution of foreign direct investment: Analysis and determinants. Regional Studies, vol. 26, no. 6, pp. 535-544.

Hill S., Munday M., 1995. Foreign manufacturing investment in France and the UK: A regional analysis of locational determinants. Tijdschrift voor Economische en Sociale Geografie, vol. 86, no. 4, pp. 311-327.

HuANG H., Wel Y.D., 2014. Intra-metropolitan location of foreign direct investment in Wuhan, China: Institution, urban structure, and accessibility. Applied Geography, vol. 47, pp. 78-88.

HUNYA G., 1998. Integration of CEEC manufacturing into European corporate structures by direct investments. Economic Policy in Transitional Economies, Moct-Most, vol. 8, no. 2, pp. 69-90.

KaraszeWSKI W., 2004. Bezpośrednie inwestycje zagraniczne. Polska na tle świata. Toruń: Dom Organizatora.

Kato Y., Yamazaki T., 1981. Changes in the offices location of the CBD of Kobe. Annals of the Japan Association of Economic Geographers, vol. 27, no. 3-4, pp. 15-32.

Korcelli-Olejniczak E., 2012. Region metropolitalny - pojęcie, struktura przestrzenna, dynamika. Prace Geograficzne, 235, Warszawa: Instytut Geografii i Przestrzennego Zagospodarowania PAN.

Liebscher K., Christl J., Mooslechner P., Ritzberger-Grünwald D. (eds.), 2007. Foreign direct investment in Europe. A changing landscape. Cheltenham UK \& Northamptom USA: Edward Elgar.

LuC S., 2000. Zagraniczne inwestycje bezpośrednie a przekształcenia strukturalne w przemyśle polskim. Monografie i Opracowania, 475, Warszawa: Szkoła Główna Handlowa.

Marinova S.T., Marinov M.A. (eds.), 2003. Foreign direct investment in Central and Eastern Europe. Aldershot: Ashgate.

ÖZDEMIR D., 2002. The distribution of foreign direct investments in the service sector in Istanbul. Cities, vol. 19, no. 4, pp. 249-259.

PakUlska T., Poniatowska-Jaksch M., 2004. Bezpośrednie inwestycje zagraniczne w Europie Środkowo-Wschodniej. Koncentracja kapitału zagranicznego w Polsce. Monografie i Opracowania, 519, Warszawa: Szkoła Główna Handlowa. 
PaVlíneK P., 1998. Foreign direct investment in the Czech Republic. Professional Geographer, vol. 50, no. 1, pp. 71-85.

PavlíneK P., 2002. Transformation of the Central and East European passenger car industry: Selective peripheral integration through foreign direct investment. Environment and Planning A, vol. 34, no. 9, pp. 1685-1709.

PavlíneK P., 2004. Regional development implications of foreign direct investment in Central Europe. European Urban and Regional Studies, vol. 11, no. 1, pp. 47-70.

PAVLíneK P., 2012. The internationalization of corporate R\&D and the automotive industry of East-Central Europe. Economic Geography, vol. 88, no. 3, pp. 279-310.

Pavlínek P., Domański B., Guzik R., 2009. Industrial upgrading through foreign direct investment in Central European automotive manufacturing. European Urban and Regional Studies, vol. 16, no. 1, pp. 43-63.

Pavlínek P., Smith A., 1998. Internationalization and embeddedness in East-Central European transition: The contrasting geographies of inward investment in the Czech and Slovak Republics. Regional Studies, vol. 32, no. 7, pp. 619-638.

PawLIK K., 2006. Studies on foreign affiliates, technology transfer and spillover effects in a transition economy: Ten years of transition reforms and FDI inflows to Poland 1993-2002. Aarhus: Department of Management and International Business, Aarhus School of Business, [PhD thesis].

Pelegrín A., Bolancé C., 2008. Regional foreign direct investment in manufacturing. Do agglomeration economies matter? Regional Studies, vol. 42, no. 4, pp. 505-522.

Poniatowska-Jaksch M., 2006. Przemysłowe bezpośrednie inwestycje zagraniczne źródłem konkurencyjności regionu. Monografie i Opracowania, 544, Warszawa: Szkoła Główna Handlowa.

Pred A.R., 1974. Major job-providing organizations and system of cities. Resource Paper, 27, Washington D.C.: Commission on College Geography, Association of American Geographers.

QIU Y., 2005. Personal networks, institutional involvement, and foreign direct investment flows into China's interior. Economic Geography, vol. 81, no. 3, pp. 261-281.
Socl A., 2007. FDI: A difficult connection between theory and empirics [in:] B. Fingleton (ed.), New directions in economic geography, Cheltenham UK \& Northamptom USA: Edward Elgar, pp. 277-314.

Stawicka M., 2007. Atrakcyjność inwestycyjna Polski. Warszawa: CeDeWu.pl.

StępniAK A., Umiński S., 1993. Polska - WE. Możliwości inwestowania na obszarze Wspólnoty. Gdańsk: Instytut Badań nad Gospodarka Rynkowq.

SZYMAŃSKI W., 2002. Globalizacja a konkurencja i mikroekonomiczne podstawy równowagi ekonomicznej [in:] W. Szymański (ed.), Przedsiębiorstwo wobec globalizacji i integracji. Warszawa: Szkoła Główna Handlowa, pp. 9-34.

ŚlesZYŃSKI P., 2002. Struktura i rozmieszczenie ośrodków zarządzania w polskiej gospodarce w 2000 r. Przeglad Geograficzny, vol. 74, no. 2, pp. 199-228.

ŚLESZYŃSKI P., 2007. Gospodarcze funkcje kontroIne w przestrzeni Polski. Prace Geograficzne, 213, Warszawa: Instytut Geografii i Przestrzennego Zagospodarowania PAN.

ŚlESZYŃSKI P., 2008. Duże przedsiębiorstwa w strukturze przestrzennej największych polskich miast. Prace Geograficzne, 217, Warszawa: Instytut Geografii i Przestrzennego Zagospodarowania PAN.

ŚLESZYŃSKI P., 2014. Headquarters of large enterprises in the spatial structure of major Polish cities. Prace Komisji Przemysłu Polskiego Towarzystwa Geograficznego, 25, pp. 178-193.

Tavares A.T., Young S., 2006. Sourcing patterns of foreign-owned multinational subsidiaries in Europe. Regional Studies, vol. 40, no. 6, pp. 583-599.

TAYlor Z., CIECHAŃSKI A., 2013. Bezpośrednie inwestycje zagraniczne w polskim transporcie. Monografie, 15, Warszawa: Instytut Geografii i Przestrzennego Zagospodarowania PAN.

TAYlor Z., CieChański A., 2014. Funkcje kontrolne wielkich miast Polski w świetle bezpośrednich inwestycji zagranicznych $w$ transporcie. Przeglad Geograficzny, vol. 86, no. 2, pp. 141-170.

TONTS M., TAYLOR M., 2010. Corporate location, concentration and performance: Large company headquarters in the Australian urban system. Urban Studies, vol. 47, no. 12, pp. 2641-2664. 
TONTS M., TAYLOR M., 2013. The shifting geography of corporate headquarters in Australia: A longitudinal analysis. Regional Studies, vol. 47, no. 9, pp. 1507-1522.

VANČURA M., 2004. Foreign direct investment in the Czech Republic [in:] E. Jakubowicz, A. Raczyk (eds.), Regionalny wymiar integracji europejskiej. Przekształcenia Regionalnych Struktur Funkcjonalno-Przestrzennych, VIII/2, Wrocław: Instytut Geografii, Uniwersytet Wrocławski, pp. 201-209.

VANČURA M., 2006. Foreign direct investment in the countries of Central Europe with the emphasis on the Czech Republic [in:] T. Michalski (ed.), The geographical aspects of the transformation process in Central and EastCentral Europe. Gdynia-Pelplin: Bernardinum, pp. $170-180$.

VARBLANE U. (ed.), 2001. Foreign direct investments in the Estonian economy. Tartu: School of Economics and Business Administration, University of Tartu.

Wel Y.H.D., Luo J., Zhou Q., 2010. Location decisions and network configurations of foreign investment in urban China. Professional Geographer, vol. 62, no. 2, pp. 264-283.

Weresa M.A., 2008. Atrakcyjność Polski dla bezpośrednich inwestycji zagranicznych [in:] M.A. Weresa (ed.), Polska: Raport o konkurencyjności 2008. Konkurencyjność sektora usług. Warszawa: Szkoła Główna Handlowa, pp. 110-125.
Wheeler J.O., 1988. Spatial ownership links of major corporations: The Dallas and Pittsburgh examples. Economic Geography, vol. 64, no. 1, pp. 1-16.

Wu F., 1999. Intrametropolitan FDI firm location in Guangzhou, China: A Poisson and negative binomial analysis. The Annals of Regional Science, vol. 33, pp. 535-555.

Wu F., 2000. Modelling intrametropolitan location of foreign investment firms in a Chinese city. Urban Studies, vol. 37, no. 13, pp. 2441 2464.

Wu J., Radbone I., 2005. Global integration and the intra-urban location of foreign direct investment in Shanghai. Cities, vol. 22, no. 4, pp. 275-286.

Yeung H.W., Poon J., Perry M., 2001. Towards a regional strategy: The role of regional headquarters of foreign firms in Singapore. Urban Studies, vol. 38, no. 1, pp. 157-183.

ZakrzeWSKA-PóŁTORAK A., 2004. Lokalizacja przedsiębiorstw z udziałem kapitału zagranicznego w dużych polskich miastach. Biuletyn KPZK PAN, 214, pp. 241-251.

Zhao S.X., Chan R.C.K., Chan N.Y.M., 2012. Spatial polarization and dynamic pathways of foreign direct investment in China 19902009. Geoforum, vol. 43, no. 4, pp. 836-850. 
http://rcin.org.pl 